\title{
Study Terminated By Sponsor
}

National Cancer Institute

\section{Source}

National Cancer Institute. Study Terminated By Sponsor. NCI Thesaurus. Code C49632.

An indication that a clinical study was stopped by its sponsor. 